(C) Dr W. Junk Publishers, Dordrecht - Printed in the Netherlands

\title{
Biogenic silica and phosphorus accumulation in sediments as indices of eutrophication in the Laurentian Great Lakes
}

\author{
C. L. Schelske, D. J. Conley, E. F. Stoermer, T. L. Newberry \& C. D. Campbell \\ Great Lakes Research Division, University of Michigan, Ann Arbor, Michigan 48109, USA
}

Keywords: paleolimnology, diatoms, nutrients, phytoplankton production

\begin{abstract}
Biogenic silica (BSi), total phosphorus (TP), and biologically available phosphorus (AVP) were measured in short cores from Lake Michigan, Lake Erie, and Lake Ontario. Peaks in BSi concentration and peaks in BSi:TP or BSi:AVP ratios provided stratigraphic signals of water column silica (Si) depletion as a response of increased diatom production to $P$ enrichment and decreased diatom production resulting from silica depletion. By contrast the stratigraphic record of $P$ accumulation provided very weak signals of the historical nutrient enrichment in the water column. These results indicate that system $P$ recycling has a higher rate constant than Si recycling and, as a consequence, that relatively small levels of $P$ enrichment can increase diatom production and sedimentation eventually causing Si depletion and Si-limited diatom production in the water mass.
\end{abstract}

\section{Introduction}

The Laurentian Great Lakes provide an ideal system in which to assess the utility of using biogenic silica (BSi) accumulation in sediments as an index of eutrophication. Diatoms, historically, have been important components of the phytoplankton assemblage and, excluding the influence of silicalimited waters, are important components in the present day flora (Stoermer, 1984). Phytoplankton growth in these systems is controlled by phosphorus $(\mathrm{P})$ supplies and $\mathrm{P}$ enrichment increases diatom production if silica (Si) supplies are not limiting (Schelske et al., 1986).

Little information is available on historical changes in the nutrient chemistry of Great Lakes waters. Historical data on total phosphorus (TP) concentrations are not available or are very limited (Beeton, 1969), but historical TP concentrations have been estimated from computer simulations (Chapra, 1977). The only useful historical data on Si concentrations are those from Lake Michigan (Schelske, 1985) where the onset of epilimnetic Si depletion occurred as recently as the late 1960s (Schelske \& Stoermer, 1971). The BSi stratigraphy of cores provides evidence that Si depletion in Lake Erie and Lake Ontario waters occurred by the late 1800s (Schelske et al., 1983; Stoermer et al., 1985a) before there are useful records of water chemistry. Here we will show: (1) that BSi accumulation in sediments provides a stronger signal of initial effects of phosphorus enrichment than accumulation of either TP or biologically available phosphorus (AVP) and (2) that ratios of either BSi:TP or BSi:AVP in the sediment stratigraphy can be used to infer the onset of $\mathrm{Si}$ limitation for diatom production and to demonstrate that BSi accumulation provides a better signal of $\mathrm{P}$ enrichment than $P$ accumulation.

\section{Methods}

Sediment cores were collected with a Benthos gravity corer (BEN) from stations in Lake Michigan, Lake Ontario, and Lake Erie. Cores were ei- 
ther collected by us or splits of Lake Erie cores were obtained from cores collected by J. A. Robbins as part of the HI-SED project. Cores were sectioned in the field, freeze dried, and analyzed for nutrients. ${ }^{210} \mathrm{~Pb}$ data for Lake Erie cores were obtained from J. A. Robbins.

Samples for BSi (ca. $30 \mathrm{mg}$ ) were weighed and leached with $\mathrm{Na}_{2} \mathrm{CO}_{3}$ at $85^{\circ} \mathrm{C}$. After 2,3 , and $4 \mathrm{hr}$ of leaching, samples were withdrawn for analysis of soluble silica on a Technicon Auto Analyzer with the hetropoly blue method. A linear regression of these time course data extrapolated to zero time was used to correct for mineral interference (Krausse et al., 1983).

Samples for AVP (ca. $50 \mathrm{mg}$ ) were leached for $17 \mathrm{hr}$ in $45 \mathrm{ml} \mathrm{NaOH}$ at $25^{\circ} \mathrm{C}$ in a shaker bath. Samples were neutralized with $0.9 \mathrm{~N} \mathrm{HCl}$, centrifuged, and analyzed for soluble reactive phosphorus. Samples for TP (ca. $50 \mathrm{mg}$ ) were digested in $20 \mathrm{ml} \mathrm{5.0 \%} \mathrm{H}_{2} \mathrm{SO}_{4}$ and $10 \mathrm{ml} 5.0 \% \mathrm{~K}_{2} \mathrm{SO}_{8}$ in an autoclave for $20 \mathrm{~min}$. Samples were neutralized with $1.8 \mathrm{~N} \mathrm{NaOH}$, centrifuged, and analyzed for soluble reactive phosphorus. Soluble reactive phosphorus was measured with an Auto Analyzer.

Atomic ratios of BSi:TP and BSi:AVP were calculated to determine effects of Si limitation on diatom production. Ratios were utilized because the results are independent of sediment dating.

\section{Results}

\section{BSi accumulation and Si depletion}

The stratigraphy of $\mathrm{BSi}$ in cores from Grand Traverse Bay, Lake Michigan, conforms with the hypothetical model proposed earlier (Schelske et al., 1983) which we interpret as evidence for epilimnetic Si depletion. The model predicts an increase in BSi accumulation in the sediments as the result of $\mathrm{P}$ enrichment until the reservoir of $\mathrm{Si}$ in the water mass is utilized and Si supplies become limiting for diatom production. In these cores, the largest increase in BSi concentrations occurred after 1940 and a decrease in BSi concentration signalling epilimnetic Si depletion occurred about 1970 (Fig. 1). The timing of the decrease in water column $\mathrm{Si}$ concentrations and the associated increase in $\mathrm{BSi}$ accumulation in the sediments corresponds to a period of increased $P$ loading beginning in the late 1940s (Fig. 2). In addition, the Si depletion signal

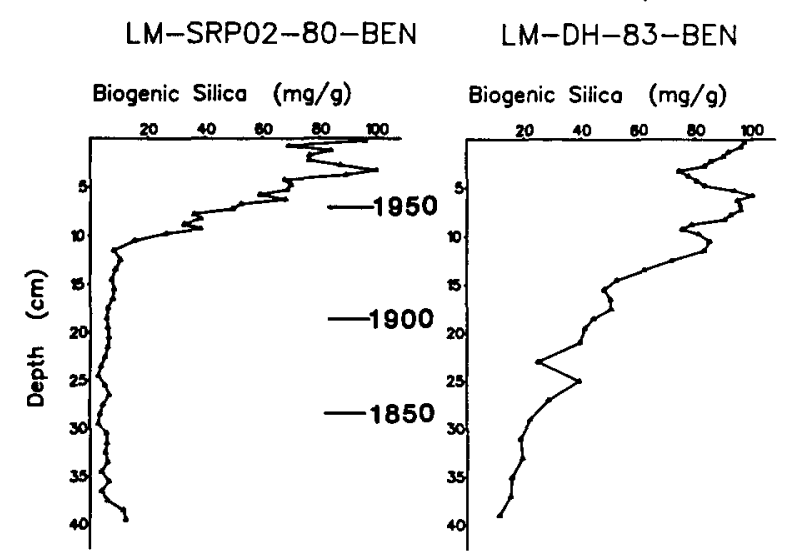

Fig. 1. Biogenic silica concentration vs. depth in cores from Grand Traverse Bay, Lake Michigan. The BSi peak at $6 \mathrm{~cm}$ in DH-83 has been dated at 1970 by stratigraphic correlation with core SRP02 (see Schelske et al., 1983).

in the sediments occurred about 1970 when it is known from experimental evidence that $\mathrm{Si}$ became limiting for diatom production (Schelske \& Stoermer, 1971).

Previous analyses of the BSi stratigraphy of single cores from Lake Ontario and Lake Erie

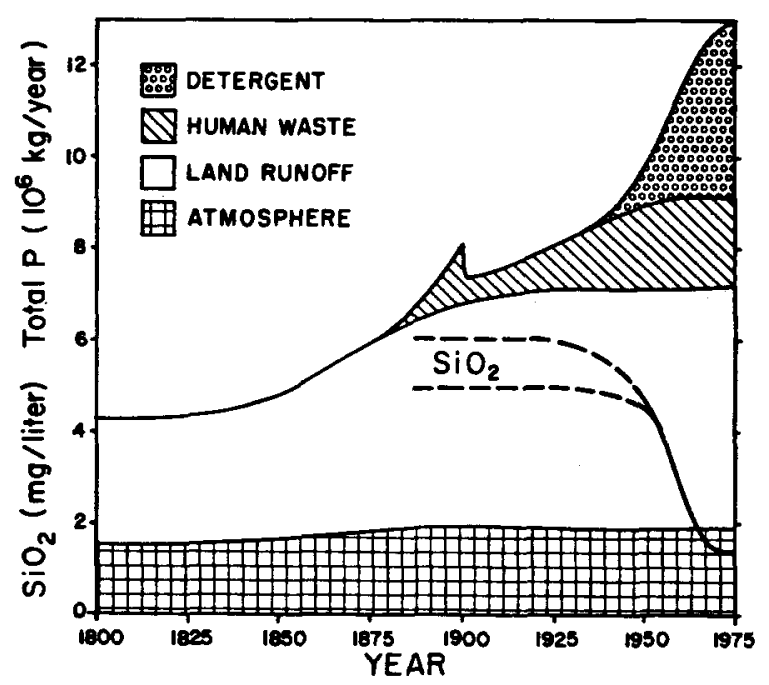

Fig. 2. Computer simulated total phosphorus loads to Lake Michigan from Chapra (1977). The curves for silica concentration represent winter maximum concentrations. The higher winter maximum $\left(6.0 \mathrm{mg} \mathrm{1}^{-1}\right)$ is based on assumptions presented by Schelske \& Stoermer (1971) and the lower value is based on data reviewed by Schelske (1985). The onset of summer epilimnetic silica limitation coincides with the reduction in winter maximum concentration to $1.4 \mathrm{mg} \mathrm{l}^{-1}$. 


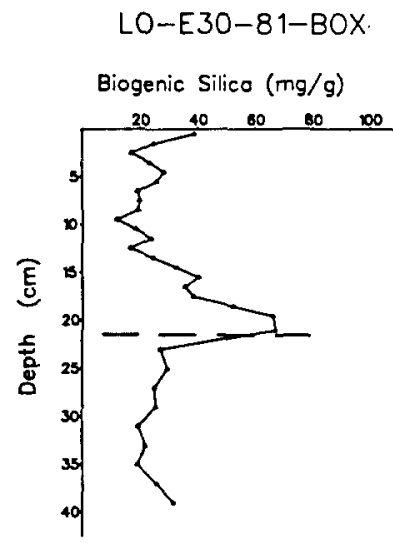

LO-E30-84-BEN
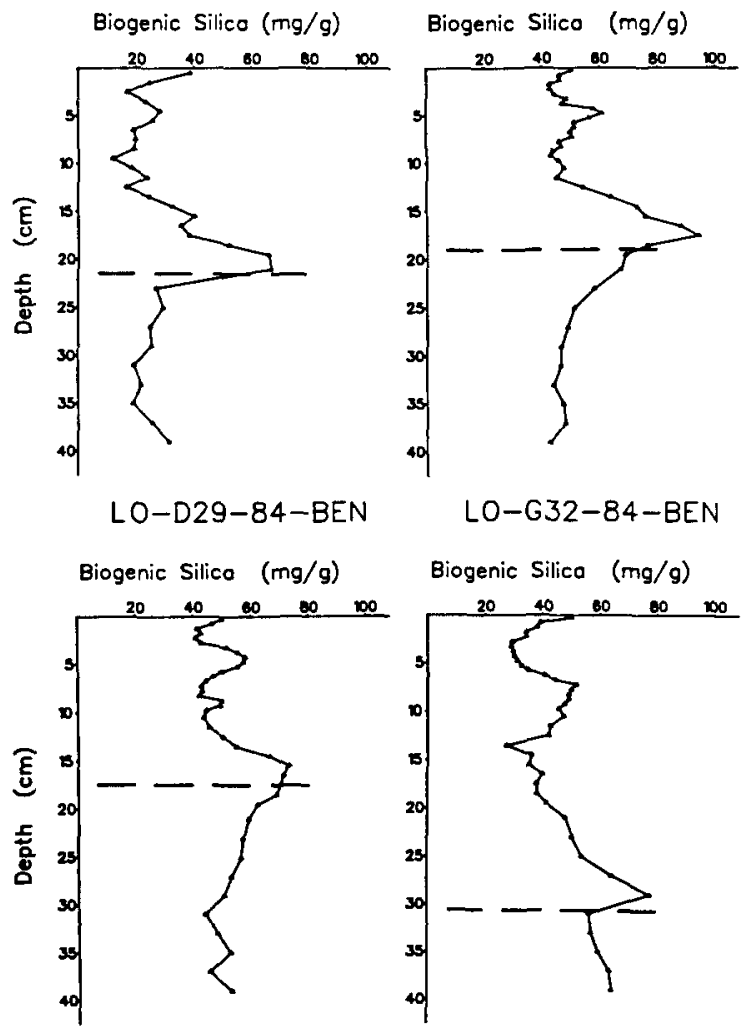

Fig. 3. Biogenic silica concentration vs. depth in cores from Lake Ontario. The post-settlement BSi peak shown by the dashed line was correlated at 1850 with the BSi peak in two ${ }^{210} \mathrm{~Pb}$ dated cores (Schelske et al., in prep.).

(Schelske et al., 1983) provide evidence that Si depletion occurred about 1850 and 1880 , respectively, during the initial stages of European settlement. These pulses of BSi were found in other cores from these lakes (Figs. 3 and 4) and occurred before simulated TP concentrations increased to $10 \mu \mathrm{g} \mathrm{P}$ $1^{-1}$ (Chapra, 1977). We believe that these early signals represent epilimnetic Si depletion. It is also apparent from closer examination of these cores that BSi concentrations increased and then decreased after 1950. We believe this secondary peak in BSi provides the stratigraphic record of events that led to severe Si depletion in Lake Ontario and the eastern and central basins of Lake Erie. Severe Si depletion reduces $\mathrm{Si}$ to $0.4 \mathrm{mg} \mathrm{SiO}_{2} \mathrm{l}^{-1}$ or less before the lake is stratified thermally (Stoermer et al., 1985a; Schelske et al., 1986).

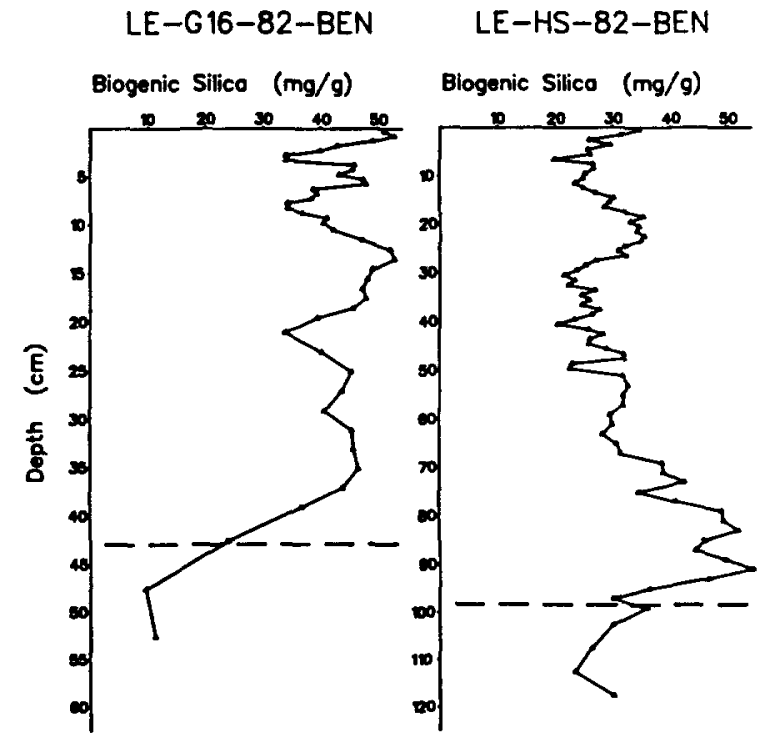

Fig. 4. Biogenic silica concentration vs. depth in cores from Lake Erie. The post-settlement rise in biogenic silica shown by the dashed line was dated at 1880 with $210 \mathrm{~Pb}$. Mass sedimentation rates calculated from ${ }^{210} \mathrm{~Pb}$ data for cores $\mathrm{G}-16-82$ and $\mathrm{Hs}-82$ were 0.108 and $0.474 \mathrm{mg} \mathrm{cm}^{-2} \mathrm{yr}^{-1}$, respectively.

\section{$P$ accumulation}

Much greater increases in $\mathrm{P}$ enrichment have occurred historically in the lower lakes than in the upper Great Lakes. Modelled TP concentrations in the lower lakes (excluding the western basin of Lake Erie) increased 5- to 6-fold, whereas in the upper lakes concentrations increased only 2 -fold at most (Chapra, 1977). Larger increases in $P$ accumulation therefore would be expected in the sediments of Lake Erie and Lake Ontario than in Lake Michigan.

Increases in $\mathrm{P}$ accumulation in Lake Ontario and Lake Erie, however, were smaller than the 5- to 6-fold increase in modelled TP concentrations. In Lake Erie, TP and AVP concentrations increased $<2$-fold in core G16 from the central basin (Fig. 5). In two cores from Lake Ontario, TP concentrations increased $<2$-fold for 10 -yr intervals between 1700 and the present while AVP concentrations increased 3-fold at most (Schelske et al., in prep). Kemp et al. (1972) also reported that TP concentrations in cores increased about 2-fold in Lake Ontario and 2- to 3-fold in Lake Erie.

Increases in $\mathrm{P}$ accumulation in Lake Michigan 

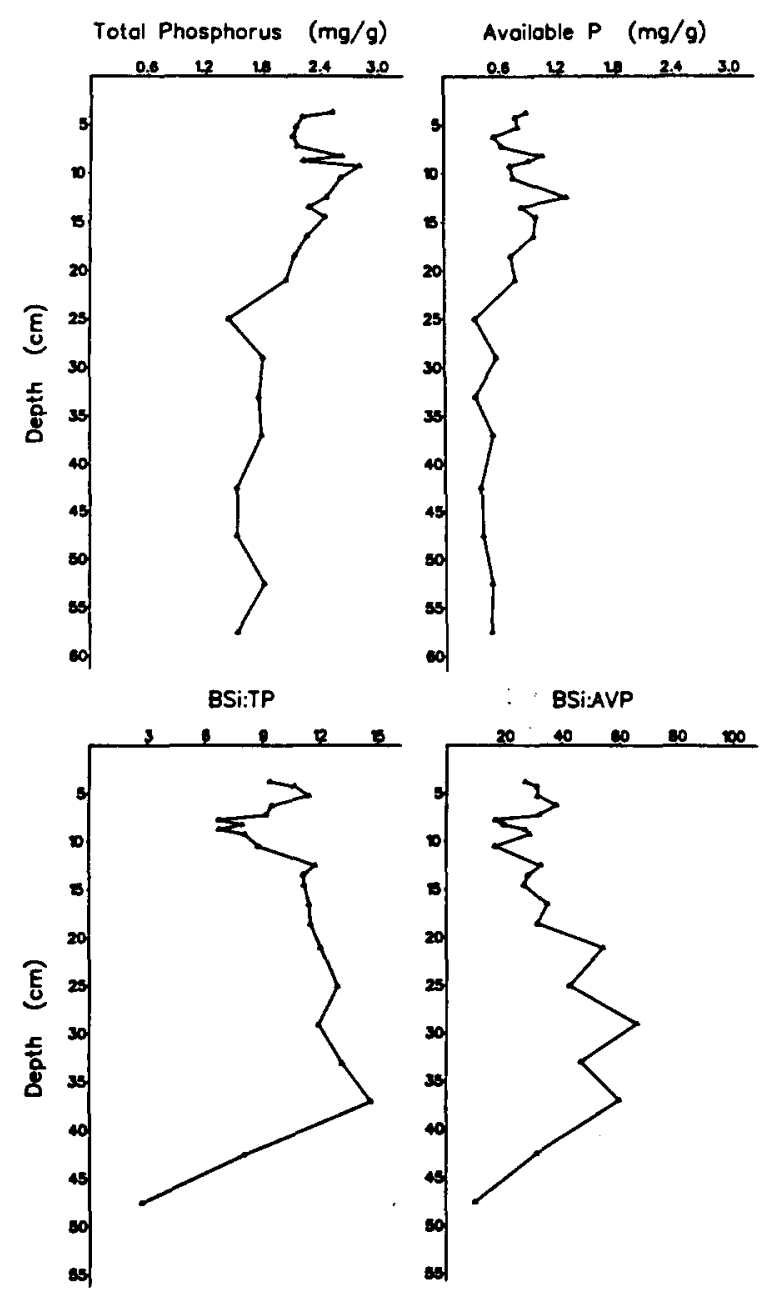

Fig. 5. Total phosphorus and biologically available phosphorus concentrations and ratios of these forms of phosphorus to biogenic silica vs. depth in core G16-82 from the central basin of Lake Erie. (see Fig. 4 also.)

cores were not apparent from concentration data except for core C37 from Green Bay (Fig. 6). But even in this core the maximum concentration was less than twice as large as concentrations found below $10 \mathrm{~cm}$ and, without the spikes in concentration of AVP and TP centered at 5 to $6 \mathrm{~cm}$, the trend for increased accumulation would be much smaller. By contrast, no obvious trend in TP or AVP concentration was found in core $\mathrm{I} 26$ or $\mathrm{K} 8$. However, TP and AVP concentrations above $10 \mathrm{~cm}$ were slightly greater than those below $10 \mathrm{~cm}$ in core $\mathrm{K} 8$ indicating that $\mathbf{P}$ enrichment had occurred in this core.
Small increases in TP and AVP concentrations found in recent sediments of cores C37 and K34 might be expected because the largest change in simulated TP loadings occurred after 1940 (Fig. 2). Greater increases in $\mathrm{P}$ accumulation normalized to annual fluxes would be obtained if an accurate estimate of pre-settlement sedimentation rates could be obtained for Lake Michigan.

Large spikes in $\mathrm{P}$ concentration common in Lake Michigan cores appeared to be the result of changes in accumulation of AVP because the spikes were found for AVP and also for TP which includes the AVP fraction. These spikes indicate that AVP storage in the sediments may be associated with episodic events. It has been suggested that sediment resuspension associated with severe storms affects the timing of permanent burial of sedimented materials (Robbins \& Edgington, 1975) and that decreases in water column TP concentrations result from winters with greater than average ice cover (Rockwell et al., 1980). Either of these processes could affect $\mathrm{P}$ storage and produce a large AVP spike in the sedimentary record. This result agrees with data from Williams et al. (1976) who reported that concentrations of apatite $P$ were fairly constant in the stratigraphy of Lake Erie cores and that recent increases in concentration of TP resulted from inputs of nonapatite inorganic $P$.

In inferring accumulation based on nutrient concentration it has been assumed that sedimentation rates were constant. Although this assumption may be valid in obtaining an average post-settlement sedimentation rate over the past 100 to $130 \mathrm{yr}$ for ${ }^{210} \mathrm{~Pb}$ dated cores, it may not be valid in comparing pre- and post-settlement sedimentation rates. If post-settlement rates in the lower Great Lakes were three times larger than pre-settlement rates and accumulation rates for $\mathrm{P}$ are adjusted accordingly, resulting post-settlement increases in TP or AVP accumulation in Lake Erie would be on the order of the 6-fold increase expected from computer simulations by Chapra (1977). Annual BSi fluxes like P fluxes for all lakes would undoubtedly be greater than the range in concentrations if these fluxes were calculated over a period which included pre-settlement stratigraphy (see Schelske et al., 1985).

\section{BSi:TP ratios}

It is apparent that the Si depletion signal based on patterns of BSi accumulation in cores from 


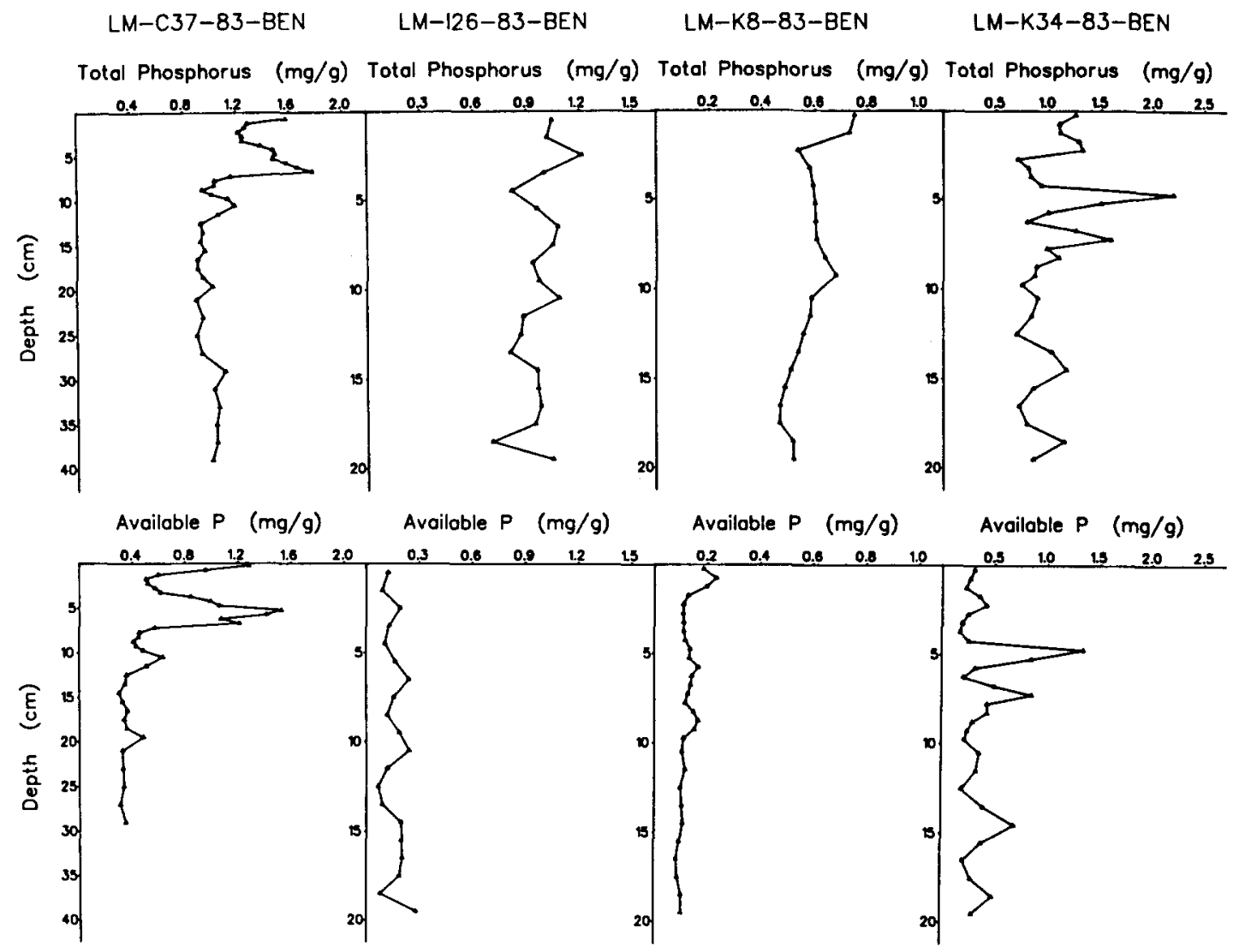

Fig. 6. Total phosphorus and biologically available phosphorus concentrations vs. depth in Lake Michigan cores. The mass sedimentation rate for core $\mathrm{K} 34$ was obtained from ${ }^{210} \mathrm{~Pb}$ measurements made in our laboratory.

Grand Traverse Bay (Fig. 1) was more pronounced than in cores from open Lake Michigan (Fig. 7). Atomic ratios of BSi:TP and BSi:AVP in the stratigraphy of open Lake Michigan cores, however, provide evidence for $\mathrm{Si}$ depletion in recent sediments. Ratios which are independent of sediment dating show that the relative increase in BSi accumulation was greater than that for TP or AVP. In general maximum ratios were found in recent sediments or at depths dated between 1967 and 1970 in K34, which coincides with the approximate time for $\mathrm{Si}$ depletion (Fig. 2). This pattern agrees with our hypothetical model in that ratios should decrease after Si became limiting for diatom production and $P$ utilization by non-siliceous phytoplankton increased. However, the earlier increase in both ratios as $P$ enrichment increased is not explained by this simple model.
Table 1. Ratios of BSi:AVP and BSi:TP in sediment cores from the Great Lakes.

\begin{tabular}{|c|c|c|}
\hline & BSi:AVP & BSi:TP \\
\hline \multicolumn{3}{|l|}{ Green Bay ${ }^{\mathrm{a}}$} \\
\hline Recent & $100-200$ & $60-90$ \\
\hline Maximum & $350-400$ & 150 \\
\hline \multicolumn{3}{|c|}{ Lake Michigana } \\
\hline Maximum & $350-400$ & $60-100$ \\
\hline \multicolumn{3}{|c|}{ Lake Ontario ${ }^{b}$} \\
\hline Recent & $10-20$ & $5-10$ \\
\hline Maximum & $50-100$ & $20-30$ \\
\hline \multicolumn{3}{|l|}{ Lake Erie ${ }^{a}$} \\
\hline Recent & $30-40$ & $10-15$ \\
\hline Maximum & $50-60$ & $10-15$ \\
\hline
\end{tabular}

a This paper.

b Schelske et al., in prep. 
Biogenic Silico $(\mathrm{mg} / \mathrm{g})$ Biogenic Silica $(\mathrm{mg} / \mathrm{g})$ Biogenic Silico $(\mathrm{mg} / \mathrm{g})$ Biogenic Silica ( $\mathrm{mg} / \mathrm{g}$ )
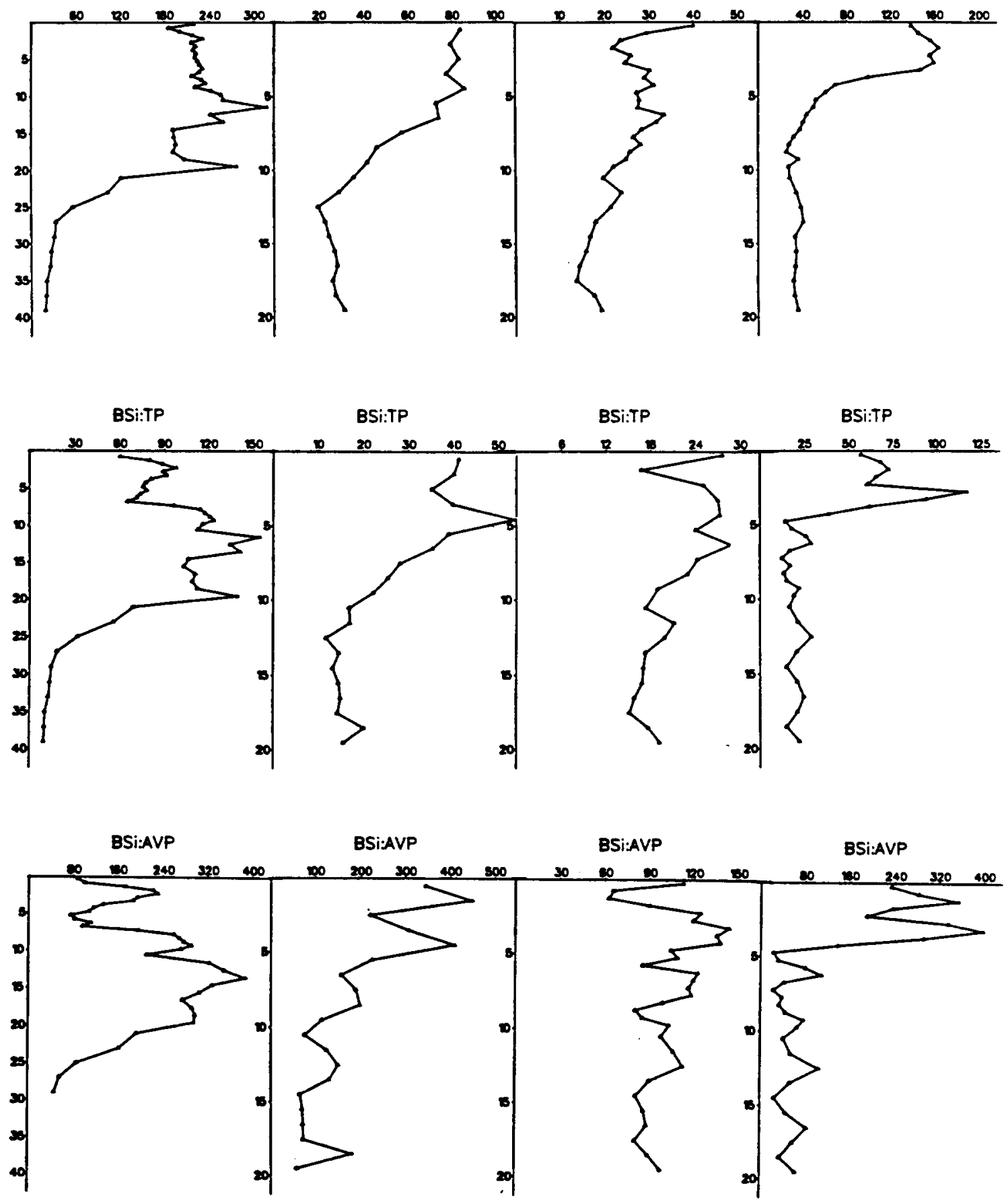

Fig. 7. Cores from Green Bay (C37) and open lake Michigan (126, K8, and K34). a. Biogenic silica concentration vs. depth, b. Ratios of BSiTP vs. depth, c. Ratios of BSi:AVP vs. depth. 
In the lower lakes, ratios also changed in response to $P$ enrichment. In core G16 from central Lake Erie, BSi:TP ratios increased soon after settlement (1850) and BSi:AVP ratios apparently peaked somewhat later (Fig. 5). Both ratios decreased in post-settlement sediments to minimum levels between 7 and $10 \mathrm{~cm}$ which according to ${ }^{210} \mathrm{~Pb}$ dates occurred between 1965 and 1972. The general decrease in the BSi:AVP ratio after post-settlement indicates that smaller fractions of AVP supplies were being utilized for diatom production and that diatom production was $\mathrm{Si}$ limited. In Lake Ontario cores, ratios of BSi:TP and BSi:AVP also increased before the period of presumed epilimnetic Si depletion in the mid 1800 s (Schelske et al., in prep.). In these cores, the increase in ratios was followed by a period in which ratios decreased rapidly so peaks in ratios corresponding in time to peaks in BSi concentration were produced. We believe that the earliest peak was associated with epilimnetic Si depletion and that either a peak in BSi concentration or in BSi:TP and BSi:AVP ratios can be used as evidence for epilimnetic Si depletion in Lake Michigan, Lake Ontario, and possibly in Lake Erie.

\section{Discussion}

The peak in BSi accumulation in the sediments which has been termed the Si depletion signal is produced because diatom production can be increased in response to $\mathrm{P}$ enrichment if $\mathrm{Si}$ supplies are available and then is decreased when the reservoir of Si in the water mass is depleted and Si becomes limiting for diatom production (Schelske et al., 1983). However, patterns of BSi accumulation will vary among the Great Lakes because of differences in morphometry, hydraulic residence time, and nutrient supplies. It follows that a deep lake would have a larger reservoir of Si than a shallower lake and that renewal of $\mathrm{Si}$ supplies from external sources would be more important in a shallow lake or shallow embayment than in deeper waters. Lake Erie is the shallowest of the Great Lakes and has the shortest hydraulic residence time. Phosphorus concentrations in Lake Erie, therefore, increased rapidly in response to nutrient loading (Chapra, 1977) and the resulting increases in diatom production depleted the Si reservoir in the water column even though Si supplies were renewed continually by inputs from Lake Huron which has relatively large Si concentrations (Schelske et al., 1983). As a consequence, post-settlement BSi production was maintained at high levels in the central basin of Lake Erie for about 100 years (Fig. 4) because a major fraction of the Si input could be utilized in diatom production, especially when $\mathrm{P}$ enrichment was adequate to produce severe Si limitation. Likewise, the period of increased BSi accumulation in the highly enriched waters of Green Bay was longer than in the less enriched waters of open Lake Michigan (Fig. 7) because Si supplies in Green Bay could be renewed from tributary inputs and by exchange of water with Lake Michigan.

Although changes in $\mathrm{BSi}$ accumulation in the sediments are caused by $P$ enrichment in the water column, changes in the accumulation of $P$ in the sediment stratigraphy were relatively small compared to those for $\mathrm{BSi}$. The largest changes were found in Lake Ontario where TP or AVP concentrations only increased 2- to 3-fold over the length of the core or a relative change comparable to the increase in BSi accumulation associated with epilimnetic Si depletion in the mid 1800s (Schelske et al., in prep.). The important difference in accumulation of the two nutrients is the greatest increase in BSi concentration occurred at a time when the increase in TP or AVP concentrations in the sediment stratigraphy was much less. Likewise, a very small increase in TP or AVP concentration or a larger increase in BSi:TP and BSi:AVP ratios was associated with the increase in BSi concentration in Lake Michigan cores.

That BSi accumulation in the sediments increased more relative to TP or AVP than either form of $P$ was evident from an examination of BSi:TP or BSi:AVP ratios. In Lake Ontario cores, a peak in BSi:TP and BSi:AVP ratios was found at the same depth as the peak in BSi accumulation associated with epilimnetic Si depletion (Schelske et al., in prep.). A peak or increase in these ratios in Lake Michigan cores also marked the time we believe that epilimnetic Si depletion occurred. The peak in ratios and increase in ratios at the onset of $\mathrm{Si}$ depletion provide evidence that BSi accumulation is a better index of eutrophication than $\mathrm{P}$ accumulation in sediments. These results are important because they demonstrate that recycling of $P$ which is primarily a biologically mediated process has a higher rate constant than the recycling of $\mathrm{Si}$ which is controlled by physical and chemical processes (Schelske et al., 1986) and that BSi ac- 
cumulation can affect the geochemistry of Si even if $90 \%$ or more of the BSi production is recycled annually (Schelske, 1985). These results also suggest that the efficiency of $\mathbf{P}$ utilization for diatom production increases with nutrient enrichment during the period in which water column silica reserves are being depleted. Shifts in diatom species composition and the provenance of diatom production or other physical, chemical, or biological factors may promote greater system efficiency in the utilization of available supplies of $\mathrm{P}$ for BSi production and sedimentation.

In summary, the record of $\mathrm{BSi}$ accumulation in the sediments of the Great Lakes provides a sensitive and general index that can be used to assess the historical impacts of $\mathrm{P}$ enrichment. BSi accumulation provides a more sensitive index of small levels of $\mathbf{P}$ enrichment than $\mathbf{P}$ accumulation in the sediments. It is sensitive enough to record effects of nutrient enrichment in Lake Superior where TP concentrations have not exceeded 4-5 $\mu \mathrm{g}$ TP $1^{-1}$ (Stoermer et al., 1985b). It provides a signal which can be used to identify epilimnetic Si depletion in Lake Michigan, Lake Erie, and Lake Ontario that resulted from $P$ enrichment to levels $<10 \mu \mathrm{g}$ TP $1^{-1}$. It also provides a secondary signal which we have associated with severe Si depletion characterized by water column Si concentrations no greater than $0.4 \mathrm{mg} \mathrm{SiO}_{2} \mathrm{l}^{-1}$ during most of the year in Lake Erie and Lake Ontario. Severe Si depletion probably results from $P$ enrichment to 15 or $20 \mu \mathrm{g}$ $T P 1^{-1}$. Identification of these stages in the trophic history of the Great Lakes has added significance because the historical chemical changes have corresponding analogues in the siliceous microfossil stratigraphy (Stoermer et al., 1985a; Stoermer et al., 1985b).

\section{Acknowledgments}

We thank John Robbins for providing splits of samples from cores taken as part of the Hi-SED project and for providing ${ }^{210} \mathrm{~Pb}$ data and Wayne Gardner for supplying phosphorus data for Lake Ontario cores. We also acknowledge grants from the National Science Foundation (OCE-8216588), Environmental Protection Agency (R810396-01), and the Michigan Sea Grant College Program (NA80-AA-D-0072) which were used to develop techniques for assay of bioavailable phosphorus.
Contribution No. 458, Great Lakes Research Division, University of Michigan.

\section{References}

Beeton, A. M., 1969. Changes in the environment and biota of the Great Lakes, pp. 150-187. In Eutrophication: causes, consequences, correctives. Nat. Acad. Sci., Washington, D.C.

Chapra, S. C., 1977. Total phosphorus model for the Great Lakes. J. Envir. eng. Div. 103: 147-161.

Kemp, A. L. W., C. B. J. Gray \& A. Mudrochova, 1972. Changes in $\mathrm{C}, \mathrm{N}, \mathrm{P}$, and $\mathrm{S}$ in the last 140 years in three cores from Lakes Ontario, Erie, and Huron. In: H. E. Allen \& J. R. Kramer (eds), Nutrients in Natural Waters, pp. 251-279.

Krausse, G. L., C. L. Schelske \& C. O. Davis, 1983. Comparison of three wet-alkaline methods of digestion of biogenic silica in water. Freshwat. Biol. 13: 73-81.

Robbins, J. A. \& D. N. Edgington, 1975. Determination of recent sedimentation rates in Lake Michigan using ${ }^{210} \mathrm{~Pb}$ and ${ }^{137}$ Cs. Geochim. Cosmochim. Acta 39: 285-304.

Rockwell, D. C., D. S. Devault, M. F. Palmer, C. V. Marion \& R. J. Bowden, 1980. Lake Michigan intensive survey 1976-1977. U.S. Environmental Protection Agency Report No. EPA-905/4-80-003-A.

Schelske, C. L., 1985. Biogeochemical silica mass balances in Lake Michigan and Lake Superior. Biogeochemistry. 1: 197-218.

Schelske, C. L. \& E. F. Stoermer, 1971. Eutrophication, silica, and predicted changes in algal quality in Lake Michigan. Science 173: 423-424.

Schelske, C. L., E. F. Stoermer, D. J. Conley, J. A. Robbins \& R. M. Glover, 1983. Early eutrophication in the lower Great Lakes: new evidence from biogenic silica in sediments. Science 222: $320-322$.

Schelske, C. L., D. J. Conley \& W. F. Warwick, 1985. Historical relationships between phosphorus loading and biogenic silica accumulation in Bay of Quinte sediments. Can. J. Fish. aquat. Sci. 42: 1401-1409.

Schelske, C. L., E. F. Stoermer, G. L. Fahnenstiel \& M. Haibach, 1986. Phosphorus enrichment, silica utilization, and biogeochemical depletion in the Great Lakes. Can. J. Fish. aquat. Sci. 43: 407-415.

Schelske, C. L., D. J. Conley, W. S. Gardner \& R. A. Bourbonniere, in prep. Biogenic silica, phosphorus, and carbon in Lake Ontario sediments.

Stoermer, E. F., 1984. Research on Great Lakes algal communities: Problems from the past, lessons for the future. J. Great Lakes Res. 10: 143-155.

Stoermer, E. F., J. A. Wolin, C. L. Schelske \& D. J. Conley, 1985a. An assessment of changes during the recent history of Lake Ontario based on siliceous microfossils preserved in the sediments. J. Phycol. 21: 257-276.

Stoermer, E. F., J. P. Kociolek, C. L. Schelske \& D. J. Conley, 1985b. Siliceous microfossil succession in the recent history of Lake Superior. Proc. Acad. Nat. Sci., Philadelphia 137: $106-118$.

Williams, J. D. H., T. P. Murphy \& T. Mayer, 1976. Rates of accumulation of phosphorus forms in Lake Erie. J. Fish. Res. Bd Can. 33: 430-439.

Accepted 18 March 1986. 